\title{
Corruption in Nigeria's Public Sector Organizations and Its Implications for National Development
}

\author{
Dr. U. E. Uwak \\ Department of Political Science and Public Administration \\ University of Uyo, Uyo \\ Anieti Nseowo Udofia \\ Department of Political Science and Public Administration \\ University of Uyo, Uyo; Email:aniudofia.owo@gmail.com
}

Doi:10.5901/mjss.2016.v7n3s1p27

\section{Abstract}

\begin{abstract}
Corruption which ever dimension has tremendous negative implications for the development and growth of any society. Corruption in the public sector involves the looting and embezzlement of public funds for personal use. On the political dimension, it involves the corrupt manner in which political leaders ascend to positions of authority. Economically, corruption involves the investment of public funds on projects that will line individual pockets rather than benefiting the generality of the populace. On the social dimension, corruption destroys the social system and makes the citizens not to have trust on the political system. The quest for self-preservation has superseded national interest and the absence of national interest manifest in lack of national development in Nigeria. The objective of this paper was to establish the correlation between corruption and national development in Nigeria. Findings revealed that corruption is albatross to national development in Nigeria. As a remedial measure, the paper recommended among others that secondary schools and higher institutions of learning should introduce corruption studies into its curriculum in order to inculcate in the students the act of discipline and educate them on the ills of corrupt practices.
\end{abstract}

Keywords: corruption, public sector, implication, anti-graft and national development

\section{Introduction}

Corruption is a recurrent decimal in Nigeria and has contributed in no small measure to the underdevelopment of Nigeria. There is corruption in high and low places ranging from embezzlement of public funds, diversion of monies meant for infrastructure development to giving of bribes for contracts and bribe in public offices. It is a phenomenon that has led to the backward and snail development in Nigeria. Everybody in the country sees the position he/she is occupying as an opportunity to amass wealth thereby making them to put their personal and selfish interest first before the interest of the nation.

The consequences of corruption in the country manifest in so many dimensions affecting all facets of human endeavour in the country. As a result of corruption, we can categorically talk about weak leadership, poor service delivery, inadequate infrastructure, poor public sector management, moral decadence and financial impropriety. The trace of these entire anomalies adversely affects the political, economic and social life of the country.

In the past years efforts have been geared towards eradicating and totally eliminating corruption in Nigeria but sadly little have been achieved in the fight against corruption. These efforts led to the establishment of such bodies like the Economic and Financial Crimes Commission (EFCC), Independent Corrupt Practices and other Offences Commission (ICPC) etc. These bodies are charged with the responsibility of arresting and prosecution of individuals found misappropriating public funds. We can state clearly that the efforts of these institutions in fighting corruption have yielded little result.

It is important to state that some times when individuals are found culpable of any offence because of their position in the society such cases are swept under the carpet and they are allowed to get away with it or are given lesser punishment compared to the offence committed. A good example is the petroleum subsidy saga involving a former member of the Upper Chamber Senator Faruk Lawan and the CEO of Capital Oil Femi Otedola. Yet another high ranking corrupt case was the one involving the former Speaker of the House of Representatives Dimeji Bankole who was 
arrested by the EFCC for corruption related case while he was the speaker of the House of Representatives. Sometimes issues of corruption because of who is involved are decided based on technicalities and not on empirical evidences. Development can only be achieved when there are strong and viable institutions. In Nigeria, our public institutions are very weak owing to corrupt practices. Such include collection and giving of bribe, contract inflation, misappropriation of funds meant for developmental projects.

Government institutions in the country have become so indifferent and have consistently neglected the general well-being of the citizens Kayode, Adagba and Anyio (2013). The public sector is supposed to be the driver of the economy which will propel national development but corruption has destroyed the society hence limiting the efficacy of the public sector's contribution to the development of the country. Despite structural reforms in the public sector aimed at combating the menace of corruption, it still prevails in Nigeria and has hindered good governance and has also robbed the masses of the social welfare that is supposed to be provided by government through its institutions.

Apart from the institutional problem, poor leadership has also contributed to the underdevelopment status of Nigeria. Ineffective leadership and corruption have impacted negatively on Nigeria's democratic stability and her economic development (Ebegbulem, 2012). It is instructive to note that majority of Nigeria's elected leaders came into office through corrupt and fraudulent manner. The aim of this paper therefore is to investigate the ignominious negative effects corruption has had on Nigeria's national development.

\section{Conceptual Clarification}

\subsection{Corruption}

The term corruption does not have a universally accepted definition. Several views have been put forward, standpoints and framework about the concept. Corruption is a concept associated with unwholesome practices in the society with its attendant negative influence. Corruption in Nigeria has been linked to the political and social problems that have bedevilled Nigeria for decades now. It can be seen to be a dishonest and unacceptable behaviour of people occupying public offices. Marriam-Webster (1990) defines corruption as inducement offered to someone which is wrong, improper or unlawful means such as bribery. Corruption can be categorized as grand, petty and political depending on the quantity of cash lost and where the corruption case occurs (Transparency International, 2015).

Corruption has many dimensions. It involves improper behaviour of public office holders such as enriching themselves, friends and loved ones to the detriment of the general populace. It is common place to see public officers divert monies that are meant for projects to their personal purse. Cases abound where public officers use public funds to acquire private property. They employ relatives and friends into government ministries and agencies under the auspices of "replacement". Replacement is a situation where a new staff is employed to fill a vacant position after the death or retirement of the original occupant of that position without approval from relevant recruitment authorities. We can go on and on to mention many of such unwholesome practices in our public sector.

It is instructive to state that the current Transparency International Corruption Index (ICP) puts the country 136 th most corrupt country in the world out of 174 that were assessed in 2014. It is very disheartening to see Nigeria rise geometrically in the corruption ladder instead of reducing. This rating is the worst in 6 years because in 2007 the corruption index puts the country as the $32^{\text {nd }}$ most corruption country out of 147 countries assessed. This goes to show that corruption has really come to stay in the country and instead of reducing it is rather increasing and has eaten deep into the political, economic and social fabrics of the country. In spite of the efforts by the anti-graft agencies, corruption cases keeps increasing as the day passes by and this has posed serious problem to Nigeria's development prospects.

According to Ogundiya (2009) since the return to civilian rule in 1999, corruption has proved to be an impediment to Nigeria's development. The resultant effect of this is seen in weak institutions and the decay in social and political spheres of Nigeria's national life. This position retards social and economic development as well as national development in the long run. The negative effect of corrupt practices manifest in political; economic; social and environmental aspects of Nigeria national engagement.

\subsection{Causes of Corruption}

Many theories have been advanced on the causes of corruption. From the stand point of this paper, the causes of corruption revolve round poverty, greed, opportunity, unemployment and the general perception of corruption in the country particularly the body language of the leaders. There are no generally acceptable causes of corruption as some writers see it as the consequence of bad governance. Yet, some other writers places premium on the ethical and morality 
standpoints. On the basis of this, corruption is seen as the consequence of the cultural and weak social values held by the people of a society. On the whole, the explanation of the causes of corruption in Nigeria is not far from the above mentioned dynamics. The factors that encouraged corruption include amongst other:

1. Bad leadership - in a country where the leaders are corrupt, the tendency for the followers to be corrupt is very high. Hence, when the leadership is corrupt the political will may not be there to fight against corrupt practices.

2. Military Rule - from independence in 1960 comparatively, the military has rolled the country for 35 years out of 55 years of Nigeria's independence. With the tendency for dictatorship, military regimes in the country administered the state without adhering to the principles of rule of law and accountability. Decisions were taken in a manner that neglected due process and accountability therefore giving avenue for corrupt practices to prevail.

3. Lack of strong legal framework work and upright judicial system that gives opportunity for prolonged and delayed legal processes in the judicial system also accounts.

4. Inequality in the society - the desire for the poor to be like the rich in the society makes them to embezzle public funds when they are in position of authority.

5. Jumbo pay for politicians - compared to what civil servants in both Federal and State governments receive monthly, political office holders are heavily paid hence civil servants who have access to government finances embezzle the funds of government in order to compete favourably with the politicians in the society.

6. The granting of office immunity to president, governors and other public office holders in the country encourage them to steal from government treasury. Cases abound in Nigeria.

7. Extreme and excessive materialism, weak ethical environment, erosion of moral values and lust for power are some of the factors that encourage corruption (Ogunlana 2007).

\subsection{Development}

The term development has many definitions as there are many authors and writers. This has resulted in the unacceptability of a particular definition. There are many dimensions of development. We can talk of economic, political and social development. Rodney (1972) corroborated this point and defines development beyond the individual or people's perception of development and conceived development whether economic, political or social to imply both increase in output and changes in the technical and institutional management by which it is produced. Development is basically the process of change in the society in all sphere of human endeavour. Development can also be seen as a multidimensional process involving fundamental changes in social structure, population, attitudes and institutions Okoye, (1997); Sahni \& Vayunandan, (2010).

Development in the words of Nkem-Onyekpe (2004), is a generic term which encompasses the transformation of the economy, state and society through the achievement of greater capacity to deal with the challenges of: (a) production and its expansion (b) political administration and governance (c) organizing the civil society as a community of people. Though the concept has been associated with such issues as economic growth, modernization, industrialization, nationbuilding, social justice and democracy; these are signs of development and not its essence. Yesufu (2000) articulated development to embrace people-centred social change, when he stated succinctly that development means people and that the essence of development is the welfare of people.

Seer (1977) gives us a guide on what development should consist when he stated that development should satisfactorily address the three central problems of poverty, unemployment and inequality. In his words, if these three societal problems are less, then there has been a period of development in a country. He stated further that if one or two of these problems are growing worse or perhaps all of the problems, it would be strange to call that development. From this standpoint, we support the views of these scholars that development should measured in terms of quality of life and wellbeing of the people in the society.

\section{Theoretical Frameworks}

The analysis of corruption practices and its implications on Nigeria's development can be explained using a mirage of theoretical perspectives ranging from idealistic theory, the resource curse theory, theory of two publics and the low riskhigh benefit theory. Idealist is premised on the thesis that individual's ideas and preferences condition their culture, behaviour and the structure of their society. We can therefore categorically say that corruption is therefore the prevalent moral values in the society. 
Resource curse theory by Auty (2004) and Ross (2001) cited in ljewereme (2015) holds that since 1960s, statistics proved that countries that are poor in resources have performed better than countries with rich resources. Accordingly, resource dependence (oil) results in the skewing of political forces. This also makes resources to be centred in one geopolitical entity and puts power into the hands of selected individuals thereby reducing the tendency for spread of development. This is a very classic case in Nigeria where the oil resources are being siphoned by top politicians for their personal and selfish use with little or no effort geared towards the socio-economic development of the nation vis-à-vis national development. The Low risk- high benefit theory is somewhat a model of deterrence to corrupt practices. It believes that in a situation where punishment for corrupt practices are light (plea-bargain) individuals will feel less bothered and corruption will continue to prevail (ljewereme, 2013).

To have theoretical explication of our phenomenon under study "corruption and national development" we will adopt the idealistic model as put forward by Nkom (1982). As noted early, the proponent holds the opinion that what people see as the ideal influence their decisions, actions and inactions in the society. As a result of this, individuals in the society who find themselves in positions of authority believe that their actions are the ideal and probably the best. It is important to note that, the action of individuals could be best for the individual but not the best for the generality of the populace. Idealism therefore is concerned with what is in opposition to realism which talks about what ought to be.

This theory sees corruption as the result of selfish ideals that are common in the society's value system. The implication is that the perception of corruption by people in the society leads to the suppression of morality and realistic values in the society. This suppression of morality in the society leads to the rising tide of immoral activities which does not promote or encourage development and it manifest in the embezzlement, siphoning and looting of monies meant for public use for personal gains. This argument sets the stage on which two positions viz the traditional and the modern schools are built.

The traditional perspective sees corruption and other unwholesome activities as the perversion of traditional African culture, values, norms, ethnics and belief system by the Western culture through Indirect Rule and Policy of Assimilation respectively. The Europeanization of Africa led Africans to embrace European culture thereby subverting the African culture and resulting in weakening of traditional values. But with time the Western values have proved capable in curbing corrupt activities.

The modernist perspective of the idealistic theory sees corruption in Nigeria as the institutionalization of African traditional societies (traditional institutions). The idea behind the idealist is that corruption is associated with several traditional practices in our society like presentation of gifts, ethnic loyalty and other parochial tendencies which are prevalent in our African society. All these tend to influence individuals in the society to look at the ideal as against what should be which is the real.

On the whole, the applicability of this theory to the work is hinged on the fact that, it $x$-rays those principal factors that influences individual's actions in public realm like people's ideas which conditions their behaviour and culture including social and moral values prevalent in the society. These inadvertently conditions the way and manner individuals behave and act in the society

\section{Public Sector and Corruption in Nigeria}

Corruption has proved to be one of the problems seriously confronting Nigeria since the return to civil rule in 1999. In fact, considering various cases of financial corruption being perpetrated in governance since 1999 till date, we can categorically say that corruption has actually been institutionalized in the country. This is so because institutions of government bribe legislatures in order to pass budgets of their organization and ministries collect bribe before contracts are awarded, politicians give money to electorates to vote them into power, contract inflation, lecturers collect money from students before they can pass examination. The dimensions of corruption are so numerous that this paper will not be able to exhaust. This therefore means that the negative impact of corruption are also countless and this has inadvertently affected the political, economic and social development of Nigeria.

The First and Second Republics in Nigeria came to an abrupt end because of corruption. During this period, people in ministries, departments and agencies of government in the First Republic stole funds and there was no policy position to stamp out corruption menace in the country. The 1964 and 1965 elections witnessed rigging by the Northern People's Congress (NPC) (Ajayi, 2008). The party in power (NPC) went against electoral guidelines and procedures and that caused the failure of other political parties most especially Action Group (AG). This led to the rejection of the outcome of the election culminating in widespread violence and outright destruction of lives and property especially in the Western part of the country. According to ljewereme and Dunmade, (2004) corruption, massive rigging of the elections, arson, killing and violence in the Western, were reasons why the middle-ranked army officers staged coup to sack the Nigerian 
First Republic politicians from power in January 15, 1965.

General Gowon's administration did not do much to end or bring corruption to the barest level in the country as corruption acts were not hidden in the public perspective. His promise to establishment anti-graft agencies to fight corruption was not actualized. However, the administration of Murtala Mohamed exposed the corruption level and activities that was perpetuated during Gowon's regime when he set up Assets Investigation Panel to probe the governors and other public office holders who worked under Gowon. The investigation led to the indictment of 10 out of 12 military governors and their assets frozen. The anti-graft exercise led to the purge of the civil service whereby over 10,000 civil servants were sacked for corrupt practices (Anazodo, Okoye and Chukwuemeka, 2012).

However, during the Second Republic, it was thought that the anti-corruption war that Murtala started would have been sustained by Shehu Shagari's civilian regime. But on the contrary, there was no deterrence on corruption acts in the public service as the politicians seriously engaged in various forms of corrupt practices without reflecting on what befell corrupt individuals during Murtala's administration.

When General Muhamadu Buhari snatched power from Shagari from the word go, he was extremely determined to stamp out corruption in the Nigerian public sector. This was done through the programme he tagged "War Against Indiscipline" (WAI). Many investigative tribunals were put in place to probe public officials of the Second Republic. Despite the anti-corruption fight of the Buhari's administration, the Babangida's administration did not key into the anticorruption campaign of his predecessor. The probe of General Babangida led to the discovery of over N 400 million wasted on the Better Life Project. Massive corruption was also revealed in the Nigerian National Petroleum Corporation and many others.

The corruption spree still continued when Abacha took over from the Interim National Government headed by Chief Ernest Shonekan. The Administration of General Abacha looted government treasury and within 5 years as the head of state, he amassed wealth that is more than that of countries in Black Africa put together (Ebegbulem, 2012). Abacha became so corrupt and dictatorial to the extent that anybody or group of persons that opposed his actions were either jailed or assassinated. Till date, Abacha's loots are still being recovered from accounts in foreign countries. But the big question is "where are the recovered funds".

When Abacha died in 1998 and Abdulsalami Abubakar became the head of state with the promise to hand over power to a duly elected civilian president, government treasury was also looted through contract inflation, licenses and appointments. The Christopher Kolade's Panel put in place to review contracts awarded during Abdulsalami's tenure made some shocking revelations. The panel submitted that the 4,072 contracts cost Nigeria N 635.62 billion as against the $\mathrm{N} 88$ billion budgeted in 1998 (Anazodo, Okoye and Chukwuemeka, 2012).

In like manner, with the return to civilian regime, one would have thought that the leaders having been duly elected by the electorates would have acted according to the principles of rule of law and in the best interest of the general populace that voted them into office, but unfortunately, the actions and inactions of Obasanjo showed no departure from the trends in previous administrations. When president Obasanjo assumed office, he stated that corruption is the major problem confronting Nigeria's development that his administration will do everything possible to eradicate corrupt practices in the society. But on the contrary, president Obasanjo for the two terms of eight years he ruled the country did not match his words with action despite the establishment of Economic and Financial Crimes Commission and Independent Corrupt Practices and other Offences Commission (ICPC) to fight corruption in the country.

It is instructive to note however that when Nuhu Ribadu was appointed to pilot the affairs of EFCC, Nigeria's corruption profile gradually declined according to Transparency International rating scale. In a 10 point scale rating in 2004, Nigeria was in 1.6 level, 1.9 in 2005, 2.2 in 2006, 2.2 in 2007 and 2.7 in 2008 (IT. 2008). The administration of Chief Obasanjo was characterized by obvious neglect to the principles of rule of law, lack of due process in the award of contracts. While passively fighting corruption, President Obasanjo in the quest to prolong his stay in power paid huge amount of money to legislators to amend the constitution to allow him contest for a third term. This therefore means that apart from corruption practices by appointees during Obasanjo's administration, he also perpetuated and encouraged corrupt practices in the country.

According to Aderonmu (2009), the administration of Obasanjo witnessed unthinkable dimensions of corrupt practices, selective investigation of corrupt public officials and inefficient handling of the economy. It has been revealed that after the expiration of Obasanjo's tenure that he bought some government property and even awarded contracts to himself (Aderonmu, 2009).

When Yar'Adua came in as Obasanjo's successor, he showed the commitment to fight corruption but his body language revealed that he was not committed to what he stood for. This was evident in his effort to stop the prosecution of James Ibori former governor of Delta State and the subsequent removal of Ribadu as the EFCC chairman. After the death of Yar'Adua, President Goodluck Jonathan who took over from him did not show courage to fight corruption as 
most of his political appointees were corrupt. They looted government treasury without conviction. The likes of the former Aviation minister Miss Stella Odua who used the ministry's finance to buy bullet proof cars for her personal use. The immediate past minister of Petroleum Resources Mrs. Diezani Allison Madueke has been accused of stealing a whooping sum of $\$ 9.3$ billion under the watch of President Jonathan. In the words of Melaye (2003b), the government of President Goodluck was unable to prosecute corrupt political office holder even those that were exposed. Jonathan showed a total lack of political will to fight corruption in Nigeria. It is instructive to note that since the inception of the current administration of President Muhammadu Buhari in May 29, 2015, efforts have been geared towards tackling corruption in the country. So many strategies have been employed by the current administration like the single treasury account for ministries, agencies and departments of government that are revenue generating.

From the foregoing, it is clear that corruption is endemic in the Nigerian state and each government despite efforts and commitments to fight it usually fail in its bid to eradicate or reduce it to the minimal level. This has led to argument as to why corruption still persists in Nigeria. Some reasons have been deduced for this to include: greed; poverty, unemployment and poor youth empowerment. Conversely, the resultant effect and implications of these anomalies leads to poor investment; rise in poverty; national crises and ultimately poor national development.

\section{Corruption and Its Effect on National Development in Nigeria}

Corruption has had political, economic and social implications in the developmental process in Nigeria. It is a clog in the development and progress of any nation because it results in high cost of project, widespread poverty, poor quality service delivery, poor access to public goods. All these undermines the concept of development and put Nigeria in a stage of underdevelopment. We shall make attempts to x-ray the implications of corruption in the various spheres of Nigeria's national life. The impacts include:

i. Implication of Corruption on the Political System: the Nigerian political system is so corruption to the extent that elections are seen as "do or die affair" where political office seekers use every means possible to win elections. Stolen monies are used to pay delegates in the case of primary elections; voters are bribed to vote for a particular political party. In recent times, the electorates no longer regard government as theirs and the acceptability of government is usually contestable because a greater number of the eligible voters are sometimes not part of the electoral process because to them, their participation will not change anything. It is instructive to note that out of $68,833,476$ million registered voters in the 2015 general election in Nigeria, less than half of those who registered voted in the presidential election representing 29,432,083 million. This clearly shows the level of apathy prevalent in the country's political system. The electoral institutions in the country are manipulated to favour certain persons especially the government in power and this weakens the opposition to the disadvantage of the citizen.

ii. Negative Effect on Economic Development: in every society, the economic structure is usually assumed to be the superstructure. Hence every other structures rest on the economic structure for survival. The decline of economic base of a country inadvertently results in the decline of every other sector. The diversion of public funds by politicians and public office holders will result in incapacitation of the government to embark on huge projects that would have alleviated the sufferings of the masses. This explains why we have uncompleted projects scattered across the country. Also some of the government revenue generating agencies misappropriates the resources that would have been channelled into government account resulting in loss of government revenue. More worrisome is the fact that these stolen monies are not always invested in Nigeria as most of them transfer the money to foreign accounts and acquire property outside the country with no attendant benefit to the domestic economy. These activities continue to retard development in Nigeria.

iii. Implications on Security: the act of corruption has the tendency to instigate insecurity challenges. The militancy in the South-South region of the country comes as a result of the embezzlement of the funds meant for the development of the region by political office holders prompting the youth of the area to take up arms in order to take part of the resources. This act has degenerated to the extent of disrupting gas supply thereby resulting in poor electricity supply across the country. Some youths have decided to take their destiny in their own hands by engaging themselves in kidnapping, political thugery. All these are crises which corruption has promoted.

iv. Decline in Social Services: the infrastructural decay in our society is sometime not due to lack of budgetary allocations but due to diversion of funds appropriated to institutions of government. Persons in position of authority in the quest to enrich themselves divert government resources meant for development to their personal purse. For example contracts are awarded to contractors and they end up abandoning the project 
halfway. Sometime government policies and programmes are not fully implemented because those implementing the programmes are corrupt minded individuals. It is important to state that, there is a case scenario where a road contract was awarded for the construction of eight lanes road but the awarding institution connived with the construction company and siphoned the money and ended up constructing just two lanes. Aside from the diversion of funds, materials purchased for specific projects are also diverted for personal use by those in charge. All these act as impediments and obstacle to development in Nigeria.

\section{The Fight Against Corruption in Nigeria: The Way Forward}

From our discourse, it is very clear that there is a correlation between corruption and the level of development in Nigeria. Development cannot thrive where corruption is the order of the day. To achieve development and growth, Nigeria must fight corruption head-long, most importantly political and economic corruptions. Though some efforts have been made towards the fight against corruption, much has not been achieved despite the establishment of anti-corruption agencies like EFCC and ICPC. It is very worrisome to note that even those who are in-charge of these anti-graft agencies are also corrupt. We now find ourselves in a situation where a corrupt person fights another corrupt person. This results in a scenario where "corruption fights corruption".

In order to fight corruption effectively in the country, there is need to review the anti-graft laws in the country to suit the current political situation. It is instructive to note that corrupt individuals in the country are sometimes given less punishment for severe offences committed thereby giving others the morale to also loot government's purse. To serve as deterrent therefore, stiffer punishments like long jail terms should be applied so as to serve as deterrence to individuals who have the intention to embezzle funds of government.

Also, the agencies of government fighting corruption in Nigeria are not independent of the executive. Since they are the creation of the executive arm of government, they tend to work according to the dictates of the executive. A case in point was that of Nuhu Ribadu's tenure as the EFCC chairman during President Obaanjo's civilian regime. During this period, persons convicted were political opponents of the president hence the prosecution was selective in nature. To have effective anti-graft agencies, these bodies must be independent of the executive arm of government to guard against interference.

As a matter of national importance, corruption studies should be introduced into the curriculum of our institutions of learning right from the secondary to higher institutions to inculcate in the minds of students who are the future leaders of the country the ills and negative effects of corruption on national development and progress. With this in mind, the young people will grow and become disciplined individuals in their places of assigned responsibilities in the society.

As a principle, the concept of separation of powers should be carefully and diligently pursued. The issue of checks and balances which is the offshoot of the concept of separation of powers should be practiced to the later by the three arms of government whereby the executive checks the activities of the legislature, the legislature through its oversight functions checks the activities of the executive and the judiciary that is the court system discharges its functions of prosecuting those found guilty of corruption cases without interference from the legislature or the executive respectively.

Another measure to combat corruption in the country is to ensure that leaders of the country lead by example. It is usually held that he who must go to equity must go with clean hands. This therefore means that any leader who is bent on fighting corruption must not engage in corrupt practices. For example, during the President Obasanjo's era though he fought corruption, he was also engaged in corrupt practices e.g. during his third term bid, he bribed the legislators with huge sum of money to amend sections of the constitution to give him legal backing to contest for a third term. Leaders must therefore lead by example.

On a very important note, the widening gap existing between the poor and rich contributes in no small measure to the corruption index in the country. This is so because the poor when they find themselves in position of authority will always want to amass wealth in order to level-up with wealthy individuals in the society. With this in mind, an individual does everything possible to steal their own share of the national cake. The gap between the rich and the poor in the society does form the basis for social vices and can result in revolution as the case may be. Bridging the gap will help to curb corruption in our society.

According to Ali (2015), in three months, the anti-corruption war by President Buhari has yielded positive outcomes owing to the commitment and the political will on the side of the president. Since taking over in May 2015 the EFCC has filed 71 high profile cases and has also seized over $\$ 6.55 \mathrm{~m}$ and $€ 248,248,340$ from 55 money laundering suspects at the airports in Lagos, Kano and Abuja. In a bid to recover some of the stolen government money, the Nigeria National Petroleum Corporation (NNPC), the Niger Delta Amnesty programme and the National Maritime and Safety Agency (NIMASA) and many others are under investigation for alleged diversion of government funds. This commitment has 
received commendations within and outside Nigeria.

It is believed strongly that everything that has a beginning must have an end. Has corruption came to be part of Nigerian political, economic and social system, it can also be eradicated if strategic and stringent measures are adopted to combat it. As John Nooanan in his book titled "Bribe" cited in Otaru (2012) opined: "as slavery was once a way of life and now... has become obsolete and is incomprehensible, so the practice of bribery in the central form of the exchange of payment for official action will become obsolete". With sincerity of purpose and commitment, Nigeria can overcome the scourge of corruption.

\section{Conclusion}

It is no exaggeration that corruption as a phenomenon has impacted negatively on the political system, economic development, peace and security as well as resulted in the decline in social services in the country. The position of this paper therefore is that development cannot be achieved if concerted efforts are not taken to curb the scourge call corruption. To eradicate or at the minimum reduce corruption, the paper recommends policy programmes to include the inclusion of corruption studies on the curriculum of secondary schools and institutions of higher learning across the country.

\section{References}

Abimbola, J.O. and Adesote, S. A. (2012). Good Governance and National Development in Nigeria: A Critical Analysis. In D.A Falade and Gbade Ikuejube (eds), Nation Building and Sustainable Development in Nigeria (pp. 23-33). Ibadan, Alafas Nigeria Company.

Aderonmu J. A. (2009). Civil society and anti-corruption Crusade in Nigeria's Fourth Republic. Journal of Sustainable Development in Africa, 13, 75-86.

Ajayi K. (2008). Election Administration in Nigeria and the Challenges of the 2007 Elections. Journal of Contemporary Politics, 1, 228249.

Ali Y (2015). Buhari's Anti-Corruption Battle Rages in Nine States. The Nation Newspaper. September 09, 2015.

Anazodo R., Okoye J. C. and Chukwuemeka E. E. O. (2012). Civil service Reforms in Nigeria: The Journey so far in Service Delivery. American Journal of Social and Management Sciences, 3, 17-29.

Auty R. (2004). ThePpolitical Economy of Growth Collapses in Mineral Economies. Minerals \& Energy—Raw Materials Report, 19(4), 315.

Balogun, T. A. (1972). The Role of Science and Technology in National Development'. In A. Adarelegbe (ed) A Philosophy of Nigerian Education, (pp.12-20. Ibadan, Heinemann Educational Books (Nigeria) Limited.

Ebegbulem J. C. (2012). Corruption and Leadership Crisis in Africa: Nigeria in Focus. International Journal of Business and Social Science, 3, 221-227.

Ebegbulem, J. C. (2012). Corruption and Leadership Crisis in Africa: Nigeria in Focus, International Journal of Business and Social Science, Vol.3, No.11, Pp221-227

Ekeh P. P. (1975). Colonialism and the two Publics: A theoretical Statement. Comparative Studies in Society and History, 17, 91-112.

Ekwueme, E. G. and Daminabo, A. F. D. (2008). Corruption in education: The Nigerian Experience. Journal of Vocational Science and Educational Development. 8(1), 109-116

ljewereme O. A. (2015). Anatomy of Corruption in Nigerian Public Sector: Theoretical Perspectives and some Empirical Explanations. Sage Journal Vol. 1 (2) pp. 5-10.

ljewereme O. B. and Dunmade E. O. (2014). Leadership crisis and Corruption in Nigerian Public Sector: Implications for Socio-Economic Development of Nigeria. International Journal of Public Administration and Management Research, 2(3), 24-38.

Imhonopi, D. and Ugochukwu M. (2013). Leadership Crisis and Corruption in the Nigerian Public Sector: An Albatross of National Development. The African Symposium: An online Journal of the African Educational Research Network. Vol. 3 No. 1

Kayode, A., Adagba, S. and Anyio S. (2013). Corruption and Service Delivery: the Case of Nigerian Public Service Wudpecker Journal of Public Administration Vol. 1(1), pp. 001 - 006.

Marriam-Webseter (1990). Webster's Ninth New Collegiate Dictionary. New York: Massachusetts.

Melaye D. (2013b). Jonathan Administration most Corrupt in History. Leadership. Retrieved from https://www.facebook.com/Leadership NGA/posts/620659491301411

Nkem-Onyekpe, J. (2004). Issues in D evelopment: Nigeria. In S. O. Akhaine (Ed.). Governance: Nigeria and the World. Lagos: CENCOD, pp. 133-147.

Obasanjo O. (1999). in Shehu A (2011). "Corruption and Conflict in Nigeria: Implications for Peace, Security and National Development" paper presented at the 'Third Republic Lecture Series' of the Institute for Peace and Conflict Resolution, Ministry of Foreign Affairs, Abuja - Nigeria, 24th November.

Ogundiya I. S. (2009). Political Corruption in Nigeria: Theoretical Perspectives and Some Explanations Kamlgi-Raj Journal of Anthropology Vol. 11 No 4 
Okoye, J. C. (1997). Modern Management Techniques and Development Administration. Onitsha: Abbot Books. Ltd.

Otaru, A. A. (2012). Corruption may be Doomed but not without a Fight. In Daily Trust, April 17.

Raji, S.M. (1999). The Role of Yoruba Language in National Development in Nigeria. In J.O Akinbi, (ed) Towards A Better Nigeria: Reflections on Contemporary Issues in the Socio-Political and Economic Development of Nigeria (pp.201-210). Ibadan: Ben Quality Prints.

Rodney W. (1972). How Europe Underdeveloped Africa. London. Bogle L'ouverture.

Ross M. L. (1999). The Political Economy of the Resource Curse. World Politics, 51, 297-322.

Sahni, P. and vanyunandan (2010). Administrative Theory. New Delhi: PHI Learning Private Limited.

Seer, D. (1967). The Meaning of Development. Brighton: Institute: UK, of Development Studies

Transparency International, 2015

Transparency International. (2008). Corruption Perception Index 2008. Available from www.transparency.org 